\title{
PENGELOLAAN KEUANGAN DANA DESA DALAM PERSPEKTIF TEORI MARILEE S. GRINDLE
}

\author{
Indriana Ayuningtias ${ }^{1}$, Syahril $^{2}$, Moh. Faisol $^{3}$ \\ ${ }^{1,2,3)}$ Fakultas Ekonomi dan Bisnis Universitas Wiraraja \\ Email: ${ }^{1}$ indriana.tyas@yahoo.com, ${ }^{2}$ syahril49@yahoo.co.id, ${ }^{3}$ faisol114@wiraraja.ac.id
}

\begin{abstract}
ABSTRAK
Kebijakan publik dapat diimplementasikan ke berbagai bidang, termasuk dalam bidang keuangan. Salah satu kebijakan dibidang keuangan adalah adanya Undang-undang Nomor 6 Tahun 2014 Tentang Desa. Dimana dari adanya peraturan tersebut ingin mengetahui proses pengelolaan keuangan desa yang ada di Desa Aengbaja Kenek. Apakah dalam penyusunannya telah mengikuti kebijakan yang telah ada. Oleh sebab itu, untuk mengetahui hal tersebut peneliti menggunakan model implementasi kebijakan dari Marilee S. Grindle, yang mana keberhasilan dari suatu implementasi dipengaruhi oleh dua variabel yaitu, variabel isi kebijakan dan variabel lingkungan implementasi. Penelitian ini adalah penelitian kualitatif dengan dengan pendekatan studi kasus. Data yang digunakan berupa hasil dari wawancara, observasi dan dokumentasi. Informan dalam penelitian ini ada dua yaitu, informan kunci dan informan pendukung. Hasil dari penelitian dan pembahasan menunjukkan bahwa implementasi dari peraturan Undang-undang Nomor 6 Tahun 2014 Tentang Desa dalam konteks pengelolaan keuangan desa yang terjadi di Desa Aengbaja Kenek sudah berjalan cukup maksimal. Dimana dalam mengelola keuangannya, Desa Aengbaja Kenek mempunyai tujuan untuk menjadikan desa yang mandiri dan mewujudkan kesejahteraan masyarakat.
\end{abstract}

Kata Kunci: Teori Marilee, Keuangan Desa, Implementasi Kebijakan

\section{INTRODUCTION}

Undang-Undang Dasar Negara

Kesatuan Republik Indonesia Tahun 1945 pasal 18 ayat (1) menyebutkan bahwa Indonesia dibagi atas daerah-daerah provinsi dan daerah provinsi tersebut dibagi atas kabupaten dan kota, dimana setiap provinsi, kabupaten dan kota mempunyai pemerintah daerah yang telah diatur di dalam undangundang. Pada saat ini tidak hanya pemerintahan daerah yang banyak diperbincangkan, namun sudah beralih ke pemerintahan desa. Karena semua ingin mengetahui dan ingin melihat dari adanya perubahan mengenai pembangunan desa yang telah diatur dalam Undang-Undang Nomor 6 Tahun 2014 tentang desa yang sudah tidak lagi menjadi bagian di dalam Undang-Undang
Nomor 32 tahun 2004 tentang Pemerintahan Daerah. Undang-Undang nomor 6 tahun 2014 pada pasal 1 menyatakan bahwa :

"Desa adalah desa dan desa adat atau yang disebut dengan nama lain, selanjutnya disebut Desa, adalah kesatuan masyarakat hukum yang memiliki batas wilayah yang berwenang untuk mengatur dan mengurus urusan pemerintahan, kepentingan masyarakat setempat berdasarkan prakarsa masyarakat, hak asal usul, dan/atau hak tradisonal yang diakui dan dihormati dalam sistem pemerintahan Negara Kesatuan Republik Indonesia”.

Desa merupakan suatu wadah yang memiliki batas wiliyah dimana desa itu sendiri dapat mengatur dan mengurus semua urusan dari pemerintahan desa yang berkecipung di dalamnya yang tujuannya 
untuk memenuhi kepentingan masyarakat setempat. Sedangkan menurut Astri (2011), Desa identik dengan peradaban lingkungan masyarakat yang miskin, tradisonalis dan kolot. Desa-desa yang ada di Indonesia akan mengalami reposisi dan pendekatan baru terkait masalah pelaksanaan pembangunan dan tata kelola pemerintahan. UndangUndang Desa memiliki visi dan rekayasa yang memberikan kewenangan lebih kepada desa terkait pelaksanaan pembangunan desa, penyelenggaraan pemerintah desa, pembinaan kemasyarakatan desa dan pemberdayaan masyarakat desa yang diambil dari hasil gagasan ide masyarakat, hak asal usul, dan adat istiadat desa. Undang-Undang Desa juga memberikan jaminan yang pasti bahwa di setiap desa akan menerima dana dari pemerintah melalui anggaran negara dan daerah yang jumlahnya jauh lebih besar dibandingkan dengan anggaran dana desa sebelumnya.

Seluruh desa yang ada di Indonesia yang jumlahnya 72000 desa diperkirakan akan menerima bantuan dana transfer yang bersumber dari Anggaran Pendapatan dan Belanja Negara (APBN). Dimana desa-desa tersebut akan memperoleh anggaran $\pm \mathrm{Rp}$. 800 juta sampai dengan Rp. 1,4 miliyar per desa. Bantuan tersebut akan disesuaikan dengan kondisi desa setempat dengan mempertimbangka luas desa, jumlah penduduk dan tingkat kebutuhan hidup di desa tersebut. Adanya dana desa yang cukup besar jumlahnya timbul banyak perhatian dari masyarakat, sehingga mendorong pemerintah untuk lebih serius dalam memajukan desa. Seluruh aktor yang berkecipung dalam pengelolaan keuangan harus mempunyai keahlian yang cukup dalam pengelolaan keuangan, sehingga kedepannya tidak akan timbul permasalahan terkait dengan pengelolaan keuangan desa seperti resiko penyelewengan, penyimpangan dan korupsi.Merujuk pada Peraturan Pemerintah Nomor 72 tahun 2005, pengelolaan keuangan desa merupakan keseluruhan kegiatan yang meliputi perencanaan, penganggaran, penatausahaan, pelaporan, pertanggung jawaban dan pengawasan sehingga desa semakin terbuka dan responsiblitas terhadap pencatatan akuntansi dan manajemen keuangannya.

Dari hal tersebut ditemukannya suatu fenomena di Kecamatan Bluto, dimana persepsi peneliti sebagai salah satu penduduk menemukan bahwa dana desa yang ada di desa Kecamatan Bluto masih tidak bisa dikatakan bersifat transparan dan akuntabel, seperti kurangnya sasaran yang tepat mengenai perolehan bantuan ke masyarakat, kurangnya sosialisasi kepada masyarakat, kurangnya bimtek secara menyeluruh untuk semua desa. Adapun pengaturan terkait dengan penggunaan dana desa pada tahun 2016 yang diatur dalam Peraturan Menteri Desa, Pembangunan Daerah Tertinggal dan Transmigrasi Nomor 21 tentang Penetapan Prioritas Penggunaan Dana Desa pada tahun 2016 sebagaimana tersurat dalam pasal 4 yang menyebutkan bahwa :

"Dana Desa diprioritaskan untuk
membiayai pelaksanaan program dan
kegiatan berskala lokal Desa bidang
Pembangunan Desa dan Pemberdayaan
Masyarakat Desa".

Dari hal di atas dapat dijelaskan bahwa prioritas penggunaan dana desa telah melibatkan adanya suatu prinsip-prinsip terkait dengan keadilan yang mengutamakan hak dan kepentingan warga desa tanpa memandang adanya perbedaan. Dalam menyusun suatu tipologi, yaitu suatu hal yang mengutamakan pertimbangan antara 


kondisi/keadaan dengan kenyataan

karakteristik dari geografis, ekonomi, dan sosiologis yang sudah dimiliki desa tersebut. Adanya hal tersebut dapat menjadi tugas yang sangat berat bagi pemerintah desa. Dengan membentuk dan menyusun suatu sistem yang baik dalam mengelola keuangannya, diharapkan pemerintah desa mampu secara mandiri menjalankan tugasnya sesuai dengan peraturan Undang-Undang yang telah berlaku dan mampu untuk mencapai tujuan yang diharapkan, sehingga dapat menghasilkan peningkatan pelayanan dan kesejahteraan yang maksimal yang ditujukan untuk kepentingan masyarakat.

Dari hal tersebut dalam mengimplementasikan kebijakan publik, peneliti memilih suatu model kebijakan publik yang berdasarkan pada teori Marilee S. Grindle. Pemilihan peneliti mencoba untuk menggunakan teori tersebut dikarenakan dalam variabel kebijakan, kita dapat melihat sejauh mana kepentingan akan target sasaran kelompok, serta manfaat yang bisa kita peroleh atau yang kita inginkan terkait dengan isi kebijakan yang didapatkan, sehingga nantinya isi dari kebijakan yang ada pada teori tersebut seperti pihak-pihak yang kepentingannya dipengaruhi, jenis manfaat yang dapat diperoleh, perubahan yang diinginkan, pengambilan keputusan, pelaksana program dan sumber yang tersedia dapat diketahui apakah isi dari kebijakam tersebut sudah tepat dan sesuai dengan program sumber daya dan program yang didukung.

Variabel lingkungan implementasi dari teori Marilee S. Grindle ini mempunyai kekuatan untuk dapat melihat dari seberapa besar para aktor yang terlibat dalam masalah pengimplementasian kebijakan tersebut dan juga dapat melihat tingkat kepatuhan dari suatu target kelompok sasaran yang kita inginkan tersebut. Sehingga dari uraian latar belakang masalah di atas, maka peneliti dapat melihat dan menilai sistem kebijakan pengelolaan keuangan desa yang ada di Kecamatan Bluto, dengan melihat apakah dari pengelolaan tersebut dapat diukur secara akuntabilitas dan transparansi dan mengelola keuangan secara relevan dan reliabel.

\section{LITERATURE REVIEW}

\section{Pengertian Dana Desa}

Desa merupakan suatu kesatuan masyarakat hukum yang memiliki batas wilayah yang mempunyai wewenang untuk mengatur dan mengurus segala urusan pemerintah, kepentingan dari masyarakat setempat, hak asal usul atau hak tradisional yang telah diakui dan dihormati dalam sistem pemerintahan NKRI. Didalam Peraturan Menteri Keuangan Republik Indonesia No. 241 Tahun 2014 pasal 1 tentang Pelaksanaan Pertanggungjawaban Transfer ke Daerah dan Dana Desa, dana desa adalah dana yang bersumber dari APBN kabupaten dan kota yang digunakan untuk membiayai penyelenggaraan pemerintahan, pelaksanaan pembangunan, pembinaan kemasyarakatan.

\section{Pengelolaan Keuangan Desa}

Keuangan desa adalah seluruh hak dan kewajiban dari desa yang dapat dinilai dengan satuan moneter/uang dan dapat berupa barang yang berkaitan dengan pelaksanaan dari hak dan kewajiban desa. (UU No. 6 Tahun 2014 : pasal 71 BAB VIII Keuangan Desa dan Aset Desa). Sumber-sumber pendapatan desa yaitu, Pendapatan Asli Desa (PADesa), Bagi hasil pajak Kabupaten/Kota, Bagian dari retribusi Kabupaten/Kota, Alokasi Dana Desa, Bantuan Keuangan dari Pemerintah, 


Pemerintah Provinsi, Pemerintah

Kabupaten/Kota dan Desa lainnya, Hibah, Sumbangan pihak ketiga.

\section{Pengertian Implementasi Kebijakan}

Implementasi kebijakan adalah suatu proses pelaksanaan dari suatu kebijakan agar dapat mencapai tujuan yang diinginkan (Kirana, 2016). Kebijakan yang baik dan dapat diimplementasikan secara maksimal akan menjadi sebuah solusi yang solutif bagi persoalan yang dihadapi oleh masyarakat. Implementasi yang gagal dapat terjadi karena suatu kebijakan tertentu yang telah dilaksanakan tetapi tidak sesuai dengan rencana.

\section{METHODS}

Metode penelitian yang digunakan adalah metode kualitatif dengan pendekatan studi kasus. Studi kasus dipilih oleh peneliti untuk menjelaskan secara mendalam pada implementasi teori Marilee S. Grindle dalam pengelolaan keuangan terkait dengan akuntabilitas dan transparansi dana desa di Desa Aengbeje Kenek. Melalui 3 informan kunci dan informan pendukung peneliti melakukan wawancara secara mendalam tentang implementasi pengelolaan keuangan dana desa, serta didukung dengan observasi langsung ke Desa Aengbeje Kenenk. Data dari hasil wawancara dan observasi dianalisis dengan menggunakan teknik analisis data kualitatif yang terdiri dari reduksi data, penyajian data, verifikasi, dan kesimpulan (Miler dan Huberman, 1992), serta divalidasi menggunakan triangulasi sumber dan metode.

\section{RESULT AND DISCUSSION}

Sebagaimana halnya yang telah terdapat pada kerangka pemikiran bab II, dimana penelitian ini menggunakan model teori implementasi kebijakan dari Marilee $\mathrm{S}$. Grindle yang mana model implementasinya lebih menekankan pada proses dalam pengelolaan keuangan, yaitu memperhitungkan realita-realita yang ada dalam menyusun suatu laporan keuangan desa. Implementasi kebijakan tidak hanya dapat digunakan dalam penjabaran mekanisme keputusan-keputusan politik ke dalam prosedur-prosedur rutin melalui saluran birokrasi, teteapi bisa lebih dari itu, implementasi kebijakan juga dapat menyangkut masalah pengalokasian dari sejumlah dana/biaya keputasan memperoleh apa yang yang dapat diperoleh dari suatu kebijakan. Keberhasilan implementasi dari suatu kebijakan, yaitu kemampuan kebijakan tersebut untuk diimplementasikan.

Dengan menggunakan model implementasi kebijakan dari Marilee $\mathrm{S}$. Grindle, penelitian ini melihat pelaksanaan Pengelolaan Keuagan Desa Aengbaja Kenek telah sesuai dengan Undang-undang Nomor 6 Tahun 2014 Tentang Desa. Secara lebih mendalam model dari implementasi kebijakan ini akan sangat membantu untuk melihat apakah faktor-faktor yang mempengaruhi implementasi kebijakan sudah cukup mendukung pada pelaksanaan kebijakan Pengelolaan Keuangan Desa Aengbaja Kenek atau masih belum mendukung.

Terkait dengan konten isi (kebijakan) pada model Marilee S. Grindle, berikut peneliti paparkan terkait dengan kebijakan pengelolaan keuangan Desa Aengbaja Kenek, yiatu sebagai berikut: 
a. Pihak yang kepentingannya dipengaruhi Suatu kebijakan akan sulit untuk diimplementasikan apabila isi dari suatu kebijakan menyangkut banyak kepentingan didalamnya. Adapun pihak yang kepentingannya sangat dipengaruhi dalam mengimplementasikan kebijakan dari Undang-undang Nomor 6 Tahun 2014 Tentang Desa terutama dalam segi pengelolaan keuanngan desanya, dimana dalam mengelola keuangan desa terutama adalah penyusunan perencanaan penggunaan APBDes.

Berikut penggalan wawancara yang dilakukan dengan Bapak Wardi selaku sekretaris Desa Aengbaja Kenek:

"yang ikut terlibat dalam pelaksanaan kebijakan Undang-Undang Nomor 6 Tahun 2014 terkait masalah Pengelolaan Keuangan Desa adalah yang pertama itu Kepala Desa yang merupakan pemegang kekuasaan pengelolaan keuangan desa, PTKPD seperti, Sekretaris Desa, Kasi dan Bendahara. Keterlibatan semua pihak dalam pelaksanaan kebijakan tersebut memang sangat diharuskan, agar dapat mengelola keuangan desa secara baik dan sesuai dengan kebijakan yang sudah ada"

Berdasarkan wawancara tersebut, pihakpihak yang terlibat dalam pelaksanaan kebijakan Undang-undang Nomor 6 Tahun 2014 terutama yang terkait dalam pengelolaan keuangan desa ada Kepala Desa Aengbaja Kenek yang merupakan pemegang kekuasaan dalam mengelola keuangan desa dan keterlibatan pihak lain seperti Sekretaris Desa, Kasi dan Bendahara Desa. Hal tersebut dilakukan agar Kepala Desa dapat mengelola keuangan desanya secara baik dan sesuai dengan kebijakan yang telah ada.
Adapun wawancara yang dilakukan dengan Bapak Subaidi salah satu Kasi Desa Aengbaja Kenek sebagai berikut.

"yang terlibat ada Bapak Kepala Desa, Sekretaris Desa, Bendahara, dan juga kasikasi Desa Aengbaja Kenek, yaitu kasi pemerintahan, kasi pembangunan dan kasi kesra. Memang dalam menjalankan kebijakan yang sesuai dengan peraturan itu harus melibatkan banyak orang supaya keuangan Desa Aengbaja Kenek dapat dikelola dengan baik dan sesuai dengan kebutuhan desa"

Dari hasil wawancara yang dilakukan dengan Bapak Subaidi ternyata sejalan dengan hasil wawancara dengan Bapak Wardi, bahwa dalam menjalankan suatu kebijkan dari undang-undang yang telah berlaku itu memang harus melibatkan banyak pihak. Seperti halnya Undang-undang nomor 6 tahun 2014 tentang Desa, Pemerintah Desa Aengbaja Kenek memang harus menjalankan isi kebijakan yang ada di dalam peraturan tersebut.

\section{b. Jenis manfaat yang bisa diperoleh}

Sebuah kebijakan yang jelas, harus memberikan manfaat yang aktual yang bukan hanya bersifat formal, ritual dan simbolis semata kebanyak pelaku lebih mudah di implementasikan dibandingkan dengan kebijakan yang kurang bermanfaat. Suatu kebijakan biasanya memiliki input atau hasil yang bersifat positif dan bisa juga bersifat negatif yang dikarenakan hal ini berkaitan erat dengan respon yang diberikan oleh objek dari kebijakan tersebut. Begitupula halnya dengan pengimplementasian kebijakan Undangundang Nomor 6 Tahun 2014 Tentang Desa terutama terkait dalam pengelolaan keuangan desa. Seperti halnya pengelolaan keuangan desa untuk penggunaan keuangan desa yang bersumber dari Anggaran Pendapatan dan 
Belanja Desa (APBDes) yang di dalamnya diatur bahwa pengelolaan kekayaan desa dilakukan untuk meningkatkan kesejahteraan dan taraf hidup masyarakat desa serta meningkatkan pendapatan desa. Oleh sebab itu, terlebih dahulu seluruh pemerintah desa harus menyusun kegiatan-kegiatan yang biayanya bersumber dari APBDes dan mengetahui manfaat yang diperoleh dari penggunaan APBDes tersebut.

Seperti halnya wawancara berikut yang dilakukan dengan Bapak Wardi selaku Sekretaris Desa Aengbaja Kenek:

"kalau berbicara masalah kegiatan-
kegiatan yang dana atau biayanya
bersumber dari APBDes itu banyak dan
semuanya sudah tertuang di dalam
RPJMDes tahunan. Seperti halnya kegiatan
penyelenggaraan pemerintahan desa,
kegiatan pembangunan desa, kegiatan
pembinaan dan pemberdayaan masyarakat
desa. Tetapi kegiatan yang istilah lebih
kami utamakan yaitu kegiatan
pembangunan desa dan kegiatan
pemberdayaan masyarakat desa. Memang,
semua kegiatan yang telah kami susun itu
harus bisa dilaksanakan semuanya dengan
baik dengan tujuan demi kemajuan desa
dan untuk memajukan kesejahteraan
masyarakat di desa kami"

Berdasarkan dari wawancara diatas, seluruh kegiatan-kegiatan yang pembiayannya bersumber dari APBDes sudah tertuang di dalam RPJMDes tahunan Desa Aengbaja Kenek. Kegiatan tersebut berupa kegiatan pembangunan desa dan kegiatan pemberdayaan masyarakat desa. Semua kegiatan yang disusun berharap dapat dilaksanakan dengan baik guna untuk kemajuan Desa Aengbaja Kenek dan demi kesejahteraan masyarakat Desa Aengbaja Kenek.
Penyusunan kegiatan-kegiatan tidak hanya sekedar untuk formalitas, tetapi dalam setiap kegiatan yang telah disusun terdapat beberapa manfaat-manfaat yang bisa diperoleh oleh seluruh warga yang ada di Desa Aengbaja Kenek. Berikut wawancara yang dilakukan dengan Sekretaris Desa Aengbaja Kenek, yaitu Bapak Wardi:

"semua kegiatan yang kami susun itu semata-mata untuk kesejahteraan seluruh masyarakat Desa Aengbaja Kenek. Dalam hal kegiatan pembangunan desa yang pertama, kegiatan pengendalian atau menormalisasikan saluran air, manfaat yang nantinya bisa diperoleh yaitu dengan adanya saluran air atau drainase maka tidak akan ada lagi genangan air pada saat musim hujan. Yang kedua kegiatan peningkatan jalan rabat beton, manfaatnya yaitu agar memudahkan jalur transportasi masyarakat karena kalau di desa itu banyak jalur-jalur transportasi yang masih berupa jalan setapak sehingga kalau musim hujan itu jalanan becek dan licin. Dalam hal kegiatan pemberdayaan masyarakat Desa Aengbaja Kenek yang pertama, kegiatan pembenahan rumah tidak layak huni (RTLH) dimana manfaat yang bisa diperoleh bisa membantu masyarakat agar memiliki rumah yang layak untuk di huni dan terjamin kesehatannya. Yang kedua kegiatan pengadaan mesin tanam dan panem bagi pertanian, yang mana manfaatnya yaitu agar hasil pertanian yang dihasilkan itu lebih baik dan kualitasnya lebih bagus. Yang ketiga yaitu, program pengadaan tempat untuk pengolahan ikan hasil laut, manfaat yang bisa diperoleh agar ketika sudah sampai pada musim ikan berlimpah, ikannya tidak terbuang percuma dan bisa dijadikan olahan yang nantinya bisa menjadi potensi baru bagi Desa Aengbaja Kenek." 
Berdasarkan dari wawancara diatas, seluruh kegiatan yang disusun ditujukan untuk kesejahteraan masyarakat Desa Aengbaja Kenek. Seperti kegiatan yang disebutkan, pertama pengendalian dan menormalisasikan saluran air atau drainase dimana manfaat yang bisa dirasakan oleh masyarakat yaitu agar tidak ada lagi genangan air pada saat musim hujan. Kedua pembenahan rumah tidak layak huni (RTLH) dimana manfaat yang diperoleh bisa membantu masyarakat agar memiliki rumah yang layak untuk ditempati, terjamin keselamatannya serta kesehatannya.

Wawancara yang dilakukan dengan Bapak Wardi yang menyatakan bahwa seluruh kegiatan yang dirancang guna untuk kesejahteraan masyarakat Desa Aengbaja Kenek. Untuk membuktikan pernyataan tersebut berikut bukti dari kegiatan pengendalian atau menormalisasikan saluran air (drainase) yang manfaatnya bagi masyarakat nantiya tidak akan ada lagi gengangan air pada saat musim hujan.

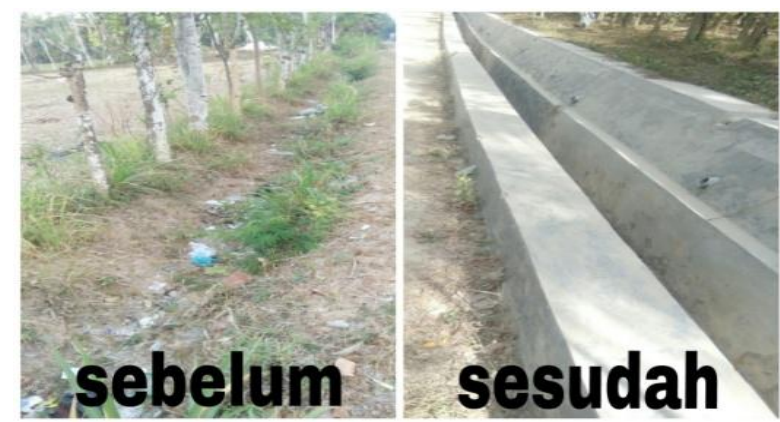

\section{Gambar 1.1}

Pengendalian Saluran Air (drainase) Desa

Aengbaja Kenek

Kegitan lainnya yang manfaat juga dapat dirasakan oleh masyarakat Desa Aegbaja Kenek yaitu kegiatan peningkatan jalan rabat beton degan tujuan agar memudahkan jalur transportasi masyarakat desa. Berikut salah satu jalan rabat beton yang ada di Desa Aengbaja Kenek yang diperoleh dari hasil observasi.

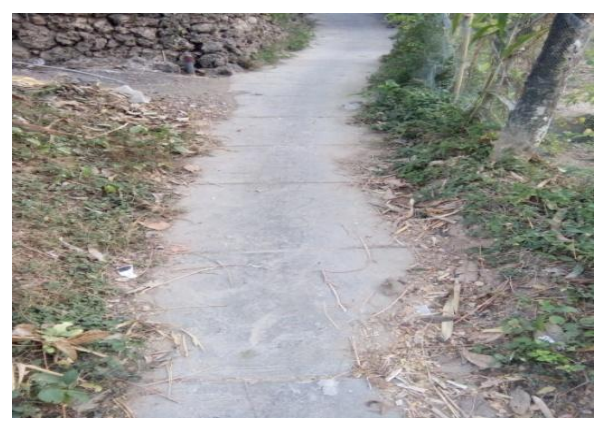

Gambar 1.2

Jalan Rabat Beton Desa Aengbaja Kenek

Hasil wawancara yang dilakukan dengan masyarakat setempat yang ikut merasakan manfaat dari adanya pembangunan saluran air dan peningkatan jalan rabat beton sebagai berikut.

"dulu itu bentuk saluran airnya kan alami jadi kalok musim hujan kadang mampet karena salurannya gak lancar banyak sampah yang nyangkut, sekarang sudah dibangun maka jalannya air itu lancar tidak mampet. Kalau pengadaan jalan rabat beton memang kami yang minta, soalnya kalau jalan setapak itu kalau musim hujan licin kadang banyak orang jatuh, jadinya kami minta ke kepala desa agar dibangun jalan beton biar kami mudah untuk menggunakan jalur transportasi tersebut"

Dari hasil wawancara yang dilakukan dapat dilihat bahwa dua kegiatan pembangunan tersebut manfaatnya memang dapat langsung dirasakan oleh masyarakat, dimana memang tujuan dari seluruh kegiatan yang disusun oleh Pemerintah Desa Aengbaja Kenek semata-semata untuk kesejahteraan masyarakat desa setempat serta keuangan desa telah digunakan untuk kebutuhan desa dan masyarakat desa.

c. Jangkauan perubahan yang diharapkan 
Manfaat yang dapat diperoleh sangat berkaitan erat dengan jangkauan perubahan yang diharapkan dari adanya suatu kebijakan. Sebuah kebijakan yang sifatnya terlalu menuntut adanya perubahan sikap dan perilaku yang signifikan akan lebih sulit untuk diimplementasikan. Di samping itu kebijakan-kebijakan yang telah dirancang untuk mencapai tujuan-tujuan jangka panjang juga dapat menemui kesulitan dalam proses implementasi dibandingkan dengan kebijakan yang secara nyata dapat memberikan keuntungan langsung terhadap kelompok sasaran.

Mencermati isi kebijakan Undangundang Nomor 6 Tahun 2014 Tentang Desa, yaitu sebagai suatu upaya pemerintah pusat kepada pemerintah desa agar bisa memperkuat ekonomi desa dan mengatasi kesenjangan pembangunan nasional. Selain itu perubahan yang diinginkan dari adanya kebijakan Undang-undang Nomor 6 Tahun 2014 Tentang Desa adalah ingin menciptakan desa yang profesional, efektif, efisien, desa yang mandiri dan lebih bisa bertanggung jawab terutama dalam mengelola keuangan desanya. Oleh sebab itu, pengelolaan kekayaan milik desa dilaksanakan berdasarkan asas kepentingan umum, fungsional, kepastian hukum, keterbukaan, efisiensi, efektivitas, akuntabilitas dan kepastian nilai ekonomi.

Berikut penggalan wawancara yang dilakukan dengan bapak Wardi selaku Sekretaris Desa Aengbaja Kenek:

"seperti yang telah saya ungkapkan tadi, dari adanya APBDes dan penyusunan program yang telah kami lakukan, kami ingin perubahan yang berupa memiliki potensi suatu produk yang khas buatan Desa Aengbaja Kenek. Seperti produk yang bahan dasarnya dari ikan laut. Dari adanya program pengadaan tempat untuk mengolah ikan laut, maka perubahan yang kami inginkan yaitu menjadikan ikan laut tersebut menjadi produk cemilan kering seperti kerupuk tengiri dan teri crispy, yang mana tujuannya selain menjadikan Desa Aengbaja Kenek lebih maju juga dapat membuka lapangan pekerjaan bagi para masyarakat desa yang masih tidak memilik pekerjaan"

Berdasarkan dari wawancara diatas, derajat perubahan yang diinginkan di Desa Aengbaja Kenek yaitu memiliki potensi berupa suatu produk yang khas buatan dari Desa Aengbaja Kenek seperti camilan kerupuk dari ikan laut. Dari program pengadaan tempat untuk mengolah hasil laut selain tujuannya menjadikan Desa Aengbaja Kenek menjadi desa yang maju, program tersebut dapat membuka lapangan pekerjaan baru bagi para masyarakat Desa Aengbaja Kenek yang masih tidak memiliki pekerjaan.

Adapun pertanyaan lainnya terkait masalah perubahan yang diinginkan di Desa Aengbaja Kenek yang dilakukan dengan Bapak Wardi selaku Sekretaris Desa Aengbaja Kenek:

"perubahan yang diinginkan untuk memajukan desa tidak hanya satu, tapi ada perubahan lainnya yang ingin kami capai yaitu mempunyai Bak TPS (Tempat Pembuangan Sampah), mesin pengolah sampah menjadi pupuk organik dan menjadikan Desa Aengbaja Kenek desa yang terang, yang awalnya Desa Aengbaja Kenek dalam segi penerangan jalan kurang, nantinya dengan program pengadaan Penerangan Jalan Umum (PJU) yang tersebar di semua dusun dapat membatu kelancaran transportasi serta Desa Aengbaja Kenek tidak lagi menjadi 


Desa yang gelap dan kekurangan
penenrangan"

Tidak hanya satu perubahan yang diinginkan oleh Desa Aengbaja Kenek. Berdasarkan dari wawancara diatas, perubahan lainnya yang diinginkan yaitu mempunyai Bak TPS (Tempat Pembuangan Sampah), mesin untuk mengolah sampah menjadi pupuk organik dan pengadaan Penerangan Jalan Umum (PJU) yang tersebar di semua dusun sehingga memudahkan jalur transportasi masyarakat Desa Aengbaja Kenek.

Berikut salah satu perubahan yang diinginkan di Desa Aengbaja Kenek yang diperoleh dari hasil observasi yaitu mengenai program pengadaan Penerangan Jalan Umum (PJU) yang tersebar diseluruh dusun yang dapat membantu akses kelancaran transportasi masyarakat desa.

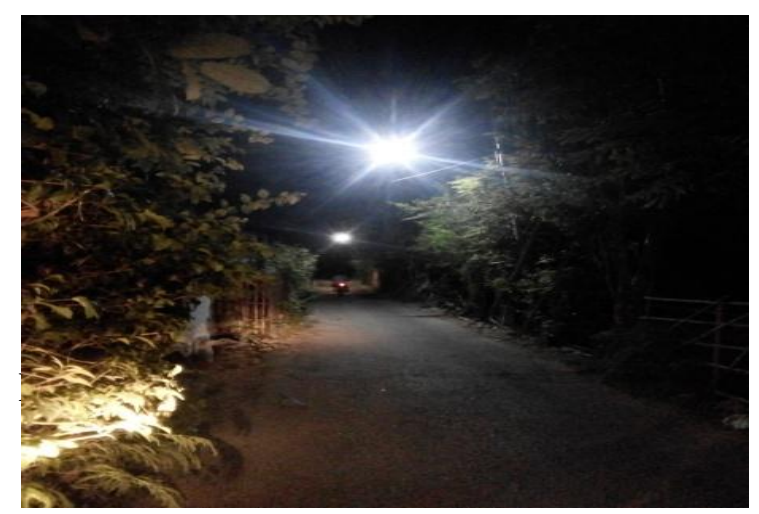

\section{d. Letak pengambilan keputusan}

Mengambil keputusan dalam sutau kebijakan memegang peranan penting dalam pelaksanaan suatu kebijakan, dimana letak pengambilan keputusan yang akan diimplementasikan harus dijelaskan terlebih dahulu. Isi dari sebuah kebijakan akan menunjukkan posisi dari pengambilan keputusan. Kebijakan di bidang tertentu biasanya diputuskan oleh sejumlah besar unit dari pengambil kebijakan. Implikasi dari jumlah pengambil keputusan adalah semakin banyak yang terlibat maka akan semakin menyulitkan di dalam implementasi kebijakannya. Demikian halnya dengan kebijakan Undang-undang Nomor 6 Tahun 2014 Tentang Desa terutama dalam mengelola keuangan desa, dimana yang memegang penuh atau memiliki kuasa penuh dalam pengelolaan keuangan desa dalah Kepala Desa.

Berikut penggalan wawancara yang dilakukan dengan Bapak Matsin selaku Kepala Desa Aengbaja Kenek:

"yang bertindak dalam mengambil
keputusan untuk pelaksanaan program
APBDes, disini kami dibantu oleh KPA
(Kuasa Pengguna Anggaran). Dalam
artian, kami dibantu dalam konteks
pengambilan keputusan terhadap
pengeluaran-pengeluaran dana yang akan
kami gunakan. Dimana dengan dibantunya
KPA kami bisa lebih mudah untuk
menggunakan APBDes untuk keperluan
desa dan masyarakat umum. Sehingga
nantinya tidak ada kabar mengenai kasus
masalah penggelapan uang desa."

Berdasarkan dari wawancara diatas, letak pengambilan keputusan di Desa Aengbaja Kenek, Kepala Desa dibantu oleh KPA (Kuasa Pengguna Anggaran). KPA membantu membuat keputusan mengenai pengeluaran-pengeluaran dana yang akan digunakan untuk kegiatan maupun program yang biayanya dari APBDes. Dengan adanya bantuan dari KPA, maka seluruh Pemerintah Desa Aengbaja Kenek dapat terhindar dari masalah penggelapan dana desa.

Letak pengambilan keputusan juga dapat dilihat dari keputusan yang diambil oleh Pemerintah Desa terkait dengan kegiatan yang akan dilaksanakan. Seperti halnya program untuk pengadaan UKM di Desa Aengbaja 
Kenek yang diinginkan oleh seluruh pemerintah desa dengan tujuan ingin memperbaiki tingkat pendapatan masyarakat Desa Aengbaja Kenek, karena jika ditelaah pada kondisi kesejahteraan KK Desa Aengbaja Kenek, mayoritas masyarakat desa didomisili dengan KK Miskin sebesar 34,5\% dari total KK keseluruhan dan jumlah masyarakat yang belumtamat SD dominan besar. Tetapi, apakah letak pengambilan keputusan yang diinginkan oleh pemerintah desa tersebut dapat diterima oleh masyarakat desa.

Berikut hasil wawancara yang dilakukan dengan Bapak Ahmad salah satu masyarakat Desa Aengbaja Kenek.

"memang sebaiknya seperti itu, setidaknya desa kami memiliki produk yang khas buatan dari desa kami sendiri, menurut saya keputusan untuk pengadaan UKM itu sudah tepat, karena program seperti itu juga bisa membantu masyarakat yang belum mempunyai pekerjaan, terutama bagi para pemuda-pemudi yang baru lulus SMA yang tidak melanjutkan kuliah"

Berdasarkan hasil wawancara yang dilakukan tersebut dapat diketahui bahwa pengambilan keputusan program yang diinginkan oleh Pemerintah Desa Aengbaja Kenek ternyata dapat diterima oleh masyarakat Desa Aengbaja Kenek, karena program tersebut dapat membantu peningkatan pendapatan masyarakat yang didomisili oleh masyarakat miskin dan banyak yang belum tamat SD.

\section{e. Pelaksana-pelaksana program}

Dalam proses implementasi dari suatu kebijakan menyangkut beberapa perilaku yang bertanggung jawab untuk melaksanakan program dan menimbulkan ketaatan pada diri kelompok sasaran. Selain itu dalam melaksanakan suatu program ada pula hal lain yang menyangkut jaringan kekuatan-kekuatan politik dan sosial yang langsung dapat mempengaruhi perilaku dari semua pihak yang terlibat dan yang pada akhirnya berpengaruh terhadap tujuan dari pelaksanaan program yang telah dirancang dan disusun, baik yang bersifat negatif maupun yang bersifat positif.

Berikut penggalan wawancara yang dilakukan dengan Sekretaris Desa Aengbaja Kenek yaitu Bapak Wardi:

"pelaksana dari seluruh program yang telah kita rancang itu adalah kita sendir sebagai pemerintah desa juga dibantu oleh seluruh masyarakat desa dengan cara gotong royong. Keikut sertaan masyarakat ke lapangan dalam pembangunan desa, agar masyarakat dapat mengetahui secara langsung tahapan dan proses pembangunan yang dilakukan oleh seluruh pemerintah desa. Seperti halnya, kegiatan pengendalian saluran air atau penataan saluran drainase, yang terjun ke lapangan dalam pelaksanaan program ini ada perangkat desa, pelaksana pembangunan seperti mandor, kepala tukang, tukang, pekerja atau tenaga buruh dan masyarakat setempat jika mau untuk ikut mengerjakan pembangunan dengan sukarela."

Berdasarkan wawancara diatas, pelaksana-pelaksana program dari kegiatankegiatan pembangunan desa adalah Pemerintah Desa Aengbaja Kenek yang dibantu oleh masyarakat desa dengan cara gotong royong. Masyarakat diikut sertakan dengan tujuan agar dapat mengetahui jika Desa Aengbaja Kenek benar-benar melakukan pembangunan desa dengan menggunakan biaya yang memang ditujukan untuk pembangunan desa. Sedangkan pelaksana lainnya dalam kegiatan pembangunan desa 
ada mandor, kepala tukang, tukang dan pekerja atau tenaga buruh.

Hal ini terbukti dengan karakteristik yang dimiliki oleh Desa Aengbaja Kenek yaitu mempunyai asas kebersamaan. Wawancara yang dilakukan dengan Bapak Wardi sebelumnya ternyata sejalan dengan jawaban dari Bapak Latif selaku warga Desa Aengbaja Kenek. Berikut penggalan wawancara yang dilakukan dengan Bapak Latif salah satu warga Desa Aengbaja Kenek:

"iya bak... saya sebagai salah satu warga Desa Aengbaja Kenek senantiasa ingin membantu setiap pelaksanaan dari program yang mereka rencanakan, terutama dalam segi pembangunan desa, karena ini sebagai salah satu bentuk partisipasi saya sebagai warga Desa Aengbaja Kenek dan bentuk kerperdulian saya karena ingin memajukan desa Aengbaja Kenek agar menjadi desa yang lebih maju lagi."

Berdasarkan wawancara di atas, Bapak Latif selaku warga Desa Aengbaja Kenek mempunyai rasa partisipatif sebagai warga Desa Aengbaja Kenek yang senantiasa membantu dari setiap pelaksanaan dari kegiatan yang diadakan oleh Pemerintah Desa, terutama dalam proses pembangunan desa dan juga sebagai keperduliannya untuk memajukan Desa Aengbaja Kenek.

\section{f. Sumber-sumber yang digunakan}

Sumber-sumber yang digunakan merupakan sumber daya, dimana sumber daya menjadi salah satu kunci kesuksesan dari suatu proses implementasi kebijakan bagi suatu desa. Maka dari itu, walaupun isi kebijakan telah dikomunikasikan dengan jelas dan konsisten, tetapi apabila implementor kekurangan sumber daya untuk melaksanakan kebijakan, maka implementasi tidak akan berjalan efektif. Sumber daya tersebut dapat berupa sumber daya manusia, sumber daya alam dan sumber daya finansial bahkan perlatan, sarana/prasarana dan lain sebagainya. Tanpa adanya dukungan sumber daya, maka sebuah kebijakan hanya menjadi dokumen yang terpapar di atas kertas saja.

Berikut penggalan wawancara yang dilakukan dengan Bapak Wardi selaku Sekretaris Desa Aengbaja Kenek:

"dalam menjalankan program yang telah kami rencanakan yang paling utama sumber daya yang paling dibutuhkan untuk mendukung jalannya pelaksanaan, yaitu sumber daya manusianya, karena jika hanya mengandalkan sumber daya alamnya saja dan kurangnya sumber daya manusia maka sumber daya alam yang tersedia tidak dapat dimanfaatkan. Begitu pula sebaliknya. Jadi sumber daya manusia yang menjadi point penting dalam suksesnya segala program dan kegiatan yang telah direncanakan."

Berdasarkan wawancara diatas, sumber daya yang digunakan untuk mendukung jalannya program yang akan dilaksanakan yaitu adalah sumber daya manusia. Sumber daya manusia merupakan elemen terpenting dalam suksesnya segala program yang telah direncanakan. Sumber daya lainnya yang dibutuhkan yaitu adalah sumber daya alam, tetapi jika hanya mengandalkan sumber daya alamnya saja dan kurangnya sumber daya manusia, maka sumber daya alam yang tersedia tidak dapat dimanfaatkan.

Sumber daya manusia yang merupakan elemen penting dalam mendukung jalannya program atau kegiatan yang akan dilaksanakan. Dari seluruh kegiatan yang yang ada, diambil salah satu contoh kegiatan penormalisasian salurana air (drainase) dimana dalam melaksanakan kegiatan tersebut 
pastinya akan membutuhkan banyak orang dan beberapa orang yang ahli di dalam bidang pembangunan tersebut. Berikut wawancara yang dilakukan dengan salah satu tukang yang melaksanakan pembangunan tersebut yaitu, Bapak Safi'.

"hal yang pertama yang dilakukan untuk memperbaiki saluran air itu dibersihkan dulu, soalnya banyak rumput dan sampahnya, terus di gali agak dalam 1 meter, dilebarin dari ukuran sebelumnya, sesudah itu penataan batu bangunan dan penyemenan"

Berdasarkan hasil wawancara tersebut dapat dibuktikan bahwa setiap pelaksanaan pembangunan desa harus menggunakan beberapa tenaga kerja yang memiliki kemampuan khusus dibidang pembangunan tersebut. Agar pelaksanaan pembangunan dapat berjalan lancar dan hasil pembangunan yang berkualitas.

Disamping isi kebijakan yang merupakan faktor untuk menentukan hasil implementasi suatu kebijakan, ada konten lingkungan implementasi yang juga menjadi aspek keberhasilan dari suatu kebijakan implementasi. Karena setiap kebijkan memerlukan pertimbangan konteks atau lingkungan dimana tindakan tersebut akan dilakukan. Pada saat implementasi kebijakan mengalami proses, banyak sekali bermucalan para aktor lain yang akan mempengaruhi jalannya kebijakan yang sudah ada, aktoraktor tersebut muncul dari berbagai pihak seperti, perencana, kelompok elit ekonomi, kelompok sasaran ataupun pelaksana.

Berdasarkan model implementasi kebijakan dari Marilee S. Grindle ada tiga indikator yang peneliti jabarkan sebagi berikut. a. Kekuasaan, kepentingan dan strategistrategi dari para aktor yang terlibat

Di dalam suatu kebijakan, harus dapat dipertimbangkan kembali masalah kekuasaan, kepentingan dan strategi-strategi dari para aktor yang terlibat dalam proses pelaksanaan dari suatu program, agar program atau kegiatan yang disusun dapat berjalan dengan lancar. Apabila hal ini tidak diperhitungkan kembali maka program yang hendak dijalankan akan jauh hasilnya dari yang diharapkan. Berikut hasil wawancara yang dilakukan dengan Bapak Wardi selaku Sekretaris Desa Aengbaja Kenek:

"iya ada... strategi yang kami gunakan untuk memperlancar jalannya kegiatan dan program yang kami rencanakan itu bertahap. Tahapan yang pertama, yaitu pengelolaan potensi desa secara terpadu untuk peningkatan kesejahteraan masayarakat desa melalui peningkatan kemampuan dari sumber daya manusia dan peningkatan sarana atau prasarana pendukung. Tahapan yang kedua, yaitu peningkatan kesejateraan dengan peningkatan taraf ekonomi masyarakat Desa Aengbaja Kenek dan mengharapkan semua daya dan upaya yang dilakukan dapat mewujudkan pemerintahan desa dalam pelayanan publik dan pembangunan ekonomi dengan meningkatkan hasil dari produk unggulan"

Berdasarkan wawancara diatas, bahwa strategi yang digunakan oleh Kepala Desa Aengbaja Kenek untuk memperlancar jalannya kegiatan yang direncanakan ada dua tahapan. Pertama meningkatkan sarana dan prasarana untuk kesejahteraan masyarakat desa. Kedua meningkatkan pelayanan publik pemerintah desa dan meningkatkan hasil dari produk unggulan sehinggan dapat meningkatkan taraf ekonomi masyarakat Desa Aengbaja Kenek.

Strategi yang kedua dari Kepala Desa Aengbaja Kenek yaitu terkait dengan 
peningkatan pelayanan publik, salah satu yaitu tersedianya gedung polindes yang memadai dan lengkap dengan alat-alat kesehatannya. Pelayan polindes Desa Aengbaja Kenek tersedia selama 24 jam. Hal tersebut dapat dilihat dari hasil wawancara yang dilakukan dengan salah satu petugas polindes yaitu Ibu Warda.

"polindes kami buka 24 jam, karena kita tidak tau ibu hamil mau melahirkan itu waktunya kapan, maka untuk menjaga keselematan ibu dan anak, kami buka polindes 24 jam. Kalau cumak sekedar mau periksa kesahatan ibu dan kandungannya itu dari jam delapan sampai jam tiga sore. Periksa juga bisa di posyandu, posyandu itu tiap bulan tiap hari Rabu minggu kedua"

Berdasarkan wawancara tersebut dapat diketahui bahwa polindes yang ada di Desa Aengbaja Kenek tersedia selama 24 jam. Pelayanan 24 jam tersebut bertujuan untuk keselamatan dan kesehatan masyarakat desa, terutama untuk ibu hamil.

\section{b. Ciri-ciri kelembagaan dan regim yang sedang berkuasa}

Dalam menjalakan suatu program ataupun kegiatan, pastinya ada lingkungan dimana suatu kebijakan tersebut dilaksanakan dan lembaga atau pihak lain yang ikut serta dalam menjalankan program dan kegiatan yang akan dilaksanakan. Dikarenakan, dalam menjalankan suatu program tidak bisa dilakukan oleh sepihak. Seperti halnya berikut penggalan wawancara yang dilakukan dengan Sekretaris Desa Aengbaja Kenek yaitu Bapak Wardi:

"ciri-ciri atau karakteristik yang dimiliki oleh Desa Aengbaja Kenek itu adalah asas kebersamaan, keterbukaan, jujur, adil, demokratis, dan dapat dipertanggungjawabkan. Kalau lembaga lainnya yang diikut sertakan itu ada KPA (Kuasa Pengguna Anggaran) yang membantu dalam tindakan pengambilan keputusan untuk pelaksanaan suatu program atau kegiatan"

Adapun wawancara yang dilakukan dengan informan yang berbeda, yaitu dengan Bapak Hadi selaku Ketua BPD Desa Aengbaja Kenek.

"asas keterbukaan kami buktikan dengan
rapat yang kami selenggarakan, dimana
kami mengundang perwakilan dari
masyarakat untuk menghadiri rapat tentang
pengelolaan APBDes, asas kebersamaan
terbukti dalam pelaksanaan dari kegiatan-
kegiatan yang diselenggarakan seperti
pembangunan saluran air, itu dikerjakan
secara gotong royong bersama masyarakat,
dapat dipertangungjawabkan itu dari hasil
keuangan yang telah dikelola kemudian
dibuat laporan, itu merupakan hasil dari
pertanggungjawaban kami,
pertanggungjawaban kepada masyarakat
yaitu papan informasi dari kegiatan yang
telah diaksnakan"

Berdasarkan hasil dari dua wawancara diatas, lingkungan dari suatu kebijakan yang diimplementasikan mempunyai nilai atau karakteristik yang dijadikan pedoman yaitu adalah asas kebersamaan, keterbukaan, jujur, adil dan dapat dipertanggungjawabkan. Dimana asas keterbukaan dibuktikan dengan keikut sertaan masyarakat desa di dalam rapat antar pemerintah desa, asas kebersamaan dilihat dari pelaksanaan kegiatan yang dilakukan secara gotong royong, dan hasil dari mengelola keuangan yang dipertanggung jawabkan dengan cara pembuatan laporan keuangan, sedangkan lembaga lainnya yang diikut sertakan itu adalah KPA (Kuasa Pengguna Anggaran) yang sifatnya membantu Kepala Desa Aengbaja Kenek dalam memutuskan mengenai masalah pengeluaranpengeluaran dana untuk pelaksanaan program atau kegiatan. 


\section{c. Tingkat kepatuhan dan adanya respon dari pelaksana}

Masalah kepatuhan dan daya tanggap berkaitan dengan tanggapan dan respon dari subjek atas isi dari kebijakan. Hal ini diukur dari tingkat kepatuhan Pemerintah Desa Aengbaja Kenek dalam menjalankan seluruh kegiatan maupun program yang telah disusun didalam RKPDes (Rencana Kerja Pemerintah Desa) yang merupakan rencana kegiatan dalam satu tahun. Apakah seluruh kegiatan yang disusun didalam RKP tersebut telah sesuai dengan kegiatan yang sebelumnya disusun didalam RPJMDes yang sifatnya menampung sekuruh kegiatan kerja pemerintah desa selama 5 tahun. Berikut hasil wawancara yang dilakukan dengan Bapak Tahir selaku Perangkat Desa Aengbaja Kenek.

"RPJMDes itu seluruh rancangan kegiatan untuk 5 tahun kedepan, pertahunnya itu dibuat RKP. Jelas sama dengan kegiatan yang disusun di RPJMDes. Soalnya kita nyusun RKP itu pedomannya sama RPJMDes, istilahnya dari kegiatan yang disusun di RPJMDes itu kami jabarkan di RKP"

Dari hasil wawancara yang telah dilakukan tersebut dapat diketahui bahwa penyusunan RKPDes ditujukan untuk rencana kerja selama 1 tahun yang dalam penyusunannya berpedoman terhadap RPJMDes yang merupakan kegiatan kerja pemerintah selama 5 tahun. Penyusunan RKPDes memang harus mengikuti rincian kegiatan yang disusun didalam RPJMDes sedangkan dalam penyusunan RPJMDes harus mengikuti peraturan perundangundangan yang telah berlaku salah satunya yaitu, Undang-undang nomor 6 tahun 2014 tentang Desa. Hal tersebut dapat dibuktikan dari hasil wawancara yang dilakukan dengan
Bapak Wardi selaku Sekretaris Desa Aengbaja Kenek.

"penyusunan RPJMDes itu kami mengikuti peraturan yang telah ada, seperti peraturan pemerintah, peraturan daerah kabupaten sumenep, peraturan menteri dalam negeri dan undang-undang, semua peraturan yang kita gunakan untuk menyusun RPJMDes telah dijabarkan didalam RPJMDes tersebut. Kalau masalah penyusunan RKP itu kan penjabaran dari kegiatan yang disusun di RPJMDes sebelumnya, sama enggaknya seluruh kegiatan yang disusun di RKP sama yang disusun di RPJMDes ya jelas sama, karena kita menyusun RKP itu melihatnya dari RPJMDes"

Hasil wawancara yang sebelumnya dilakukan dengan Bapak Tahir sejalan dengan hasil wawancara dari Bapak Wardi yang menyatakan bahwa penyusunan RKP merupakan penjabaran dari RPJMDes yang dibuat untuk jangka waktu 1 tahun. Dalam penyusunan RPJMDes Pemerintah Desa Aengbaja Kenek mengikuti peraturan yang telah berlaku, salah satunya yaitu peraturan Undang-undang nomor 6 tahun 2014 tentang desa.

\section{CONCLUSION}

Berdasarkan hasil penelitian dan pembahasan mengenai implementasi peraturan Undang-undang No. 6 Tahun 2014 yang terkait dalam pengelolaan keuangan desa yang ada di Desa Aengbaja Kenek, diukur melalui model implementasi dari Grindle dengan dua variabel yaitu, isi kebijakan dan lingkungan implementasi dengan beberapa indikator di masing-masing variabel tersebut. Variabel isi kebijakan ada 6 indikator dan lingkungan implementasi ada 3 indikator, maka keseluruhan ada 9 idndikator. Dari 9 indikator, 8 indikator yang digunakan untuk mengukur keberhasilan dapat dikatan cukup baik dalam mematuhi isi dari peraturan 
undang-undang tersebut, sedangkan ada satu indikator yaitu letak pengambilan keputusan, pemerintah Desa Aengbaja Kenek belum mematuhi dari peraturan yang sudah ada, dimana yang bertindak dalam mengambil keputusan dari penggunaan APBDes adalah KPA (Kuasa Penggunan Anggaran). Maka dari itu, Desa Aengbaja Kenek tidak mengikuti kebijakan yang telah ada.

\section{REFERENCES}

Abdul Wahab, Solichin. 2008. Pengantar Analisis Kebijakan Publik. Malang: UPT Penerbitan Universitas Muhammadiyah Malang.

Akang, Akasius. 2015. Kesiapan Pemerintah Desa Landungsari Menghadapi Implementasi Alokasi Dana Desa Sesuai Dengan Undang-undang Nomor 6 Tahun 2014. JISIP: Jurnal Ilmu Sosial dan Ilmu Politik4(1). 139-144

Arafat, Nur. 2014. Implementasi Peraturan Daerah No. 2 Tahun 2008 Tentang Pengelolaan Zakat Pada Tahun 20122014 (Studi pada Badan Amil Zakat Daerah/BAZDA Kota Bekasi Tahun 2012-2014). 1-15

Furqani, Astri. 2010. Pengelolaan Keuangan Desa Dalam Mewujudkan Good Governance (Studi pada Pemerintahan Desa Kalimo'ok Kecamatan Kalianget Kabupaten Sumenep). UPN. Jatim

Hamzah, Ardi. 2015. Tata Kelola Pemerintahan Desa Menuju Desa Mandiri, Sejahtera dan Partisipatoris. Surabaya: Pustaka

Harsoyo.1997. Manajemen Kinerja. Jakarta:Persada
Indah, Hanifa Suci. 2015. Akuntabilitas dan Transparansi Pertanggungjawaban Aggaran Pendapatan Belanja Desa (APBDes).Jurnal Ilmu dan Riset Akuntansi 4(8).1-15

Kholmi, Masiyah. 2016. Pengelolaan Alokasi Dana Desa: Studi di Desa Kadungbetik Kecamatan Kesamben Kabupaten Jombang.Ekonomika-Bisnis 7(2).143152

Kirana, Candra. 2016. Implementasi Purwako Pariaman Nomor 29 Tahun 2012 tentang Pengaturan Lalu Lintas Angkutan Penumpang dan Barang dalam Daerah Kota Pariaman

Narbuko,Cholid. 2009. Metodologi Penelitian.Jakarta:PT Bumi Aksara

Puji Astuti, Titiek dan Yulianto. 2016. Good Governance Pengelolaan Keuangan Desa Menyongsong Berlakunya UndangUndang Nomor 6 Tahun 2014.Berkala Akuntansi dan Keuangan Indonesia 1(1).1-14

Riyanto, Teguh. 2015. Akuntabilitas Finasial Dalam Pengelolaan Alokasi Dana Desa (ADD) Di Kantor Desa Perangat Selatan Kecamatan Marangkayu Kabupaten Kutai Kartanegara.eJournal Administrasi Negara 3(1).119-130

RPJM Desa Aengbaja Kenek Tahun 2015 2020

Sugiyono. 2016. Metode Penelitian Kualitatif. Bandung:Alfabeta

Undang-undang Republik Indonesia Nomor 6 Tahun 2014 tentang Desa

Wardoyo. 1980. Kamus Besar Bahasa Indonesia. Balai Jakarta. 